\title{
Bahan Ajar Berhitung Cepat Dengan Aplikasi Game Adobe Flash Untuk Pembelajaran Matematika Di Sekolah Dasar
}

\author{
Doni Septu Marsa Ibrahim ${ }^{1}$, Aswasulasikin' ${ }^{2}$, Muhammad Hidayatullah ${ }^{3}$ \\ Program Studi Pendidikan Guru Sekolah Dasar ${ }^{1,2,3}$ \\ Email: janganletih@gmail.com ${ }^{1}$, kien.ip12@gmail.com²
}

\begin{abstract}
Abstrak
Di era keterbukaan teknologi dan informasi dan percepatan perubahan sosial masyarakat menuntut setiap individu dapat beradaptasi dengan cepat mengikuti perubahan tersebut, Sehingga pada penelitian ini berfokus pada tujuan untuk menghasilkan Bahan Ajar Berbasis Aplikasi Game Adobe Flash CS3 pada materi penjumlahan dan pengurangan kelas II Sekolah Dasar yang layak dan valid, praktis dan efektif. Penelitian ini merupakan jenis penelitian dan pengembangan (Research and Development), langkah-langkah berpedoman pada model ADDEI yaitu: (1) Analisis, (2) Desain, (3) Pengembangan, (4) Implementasi, (5) Evaluasi. Dari hasil penelitian ini dapat diketahui tingkat kelayakan bahan ajar dari instrumen validasi ahli bahan ajar yang dikembangkan, diperoleh hasil angket penilaian oleh ahli materi dan ahli tampilan. Penilaian bahan ajar dari kedua ahli diperoleh skor 4 dari maksimal 5 untuk tiap pernyataan. Untuk masing-masing ahli materi mendapatkan nilai rata-rata 4 dan ahli tampilan mendapat nilai rata-rata 3,6. Dari sisi pengguna yaitu siswa diperoleh respon siswa terhadap bahan ajar dengan nilai rata-rata 4,2 yang berarti pengembangan Bahan Ajar dengan aplikasi Game dapat dikatakan layak dan memenuhi syarat untuk di disiminasikan sebagai bahan ajar yang efektif.
\end{abstract}

Kata Kunci: Bahan Ajar, Aplikasi Game Adobe Flash 


\section{PENDAHULUAN}

Penggunaan media yang atraktif dalam pembelajaran menjadi suatu kebutuhan yang lumrah bagi pendidik maupun pengajar saat ini. Satu dekade sebelumnya pendidik yang inovatif menciptakan metode maupun model pembelajaran yang menarik dengan menggunakan peralatan dan perangkat pertukangan di mana media tersebut dapat digunakan siswa untuk berinteraksi secara fisik. Kelebihannya siswa dapat langsung belajar sambil bermain dengan tingkat interaksi sosial yang tinggi, kerena umumnya media tersebut digunakan bersamasama teman yang lain. Saat ini terjadi transformasi media pembelajaran dari yang bersifat analog menjadi digital dan cenderung soliter, anak dapat belajar menggunakan media pembelajaran berupa aplikasi tanpa harus bersama-sama dengan orang lain. Hal ini menjadi tantangan tersendiri bagi pendidik untuk mengelola pembelajaran berbasis digital tanpa melupakan unsur sosial dan kebersamaan. Berdasarkan hal tersebut, sudah seharusnya pendidik menggunakan berbagai sumber belajar bertema teknologi komunikasi, informasi, yang ramah bagi anak.

Media pembelajaran dapat diterapkan dalam setiap mata pelajaran namun perlu memperhatikan karakteristik masing-masing topik bahasan misalnya Matematika. Pembelajaran matematika secara umum bersifat abstrak sehingga media pembelajaran yang dapat mengaktualisasikan konsep-konsep matematika sangat menarik dan perlu dikembangkan lebih luas lagi. Menurut Susanto, (2014:185). Matematika merupakan salah satu disiplin ilmu yang dapat meningkatkan kemampuan berpikir dan berargumentasi, memberikan kontribusi dalam penyelesaian masalah sehari-hari dan dalam dunia kerja, serta memberikan dukungan dalam pengembangan ilmu pengetahuan dan teknologi. Kebutuhan akan aplikasi matematika saat ini dan masa depan tidak hanya keperluan sehari-hari, tetapi terutama dalam dunia kerja, dan untuk mendukung perkembangan ilmu pengetahuan. Oleh karna itu, matematika sebagai ilmu dasar yang perlu dikuasai dengan baik oleh siswa, terutama sejak usia sekolah dasar.

Pelajaran Matematika adalah salah satu mata pelajaran wajib diajarkan kepada siswa dari tingkat SD sampai SMA. Jumlah jam paling banyak, 5 jam pelajaran per minggu membuktikan bahwa mata pelajaran matematika membutuhkan perhatian lebih banyak daripada mata pelajaran lainnya. Bagi guru, mata pelajaran 
matematika membutuhkan kerja keras untuk membimbing siswa untuk mencapai kriteria yang sudah ditentukan atau Kriteria Ketuntasan Minimal (KKM). Bagi siswa, secara umum pelajaran matematika menjadi pelajaran yang menakutkan dalam pembelajaran, tidak jarang siswa banyak yang gagal hanya karena satu mata pelajaran yaitu matematika. Pelajaran matematika sebagai mata pelajaran yang identik dengan berhitung dan selalu bergelut dengan angka-angka salah satu faktor yang membuat siswa malas mempelajarinya. Hal yang demikian harus benar-benar diluruskan oleh guru matematika sekolah dasar mulai dari sekarang.

Berdasarkan pendapat banyak ahli dan praktisi secara umum menunjukkan bahwa pembelajaran matematika masih memiliki kekurangan di antaranya kurangnya kemampuan berpikir dalam proses pembelajaran. Permasalahan paling utama adalah guru masih kurang mampu dalam mengembangkan bahan ajar berbasis teknologi dalam pembelajaran matematika berhitung cepat, selain itu bahan ajar yang digunakan guru kurang menarik bagi siswa, sehingga keaktifan dalam proses pembelajaran masih bersifat monoton, serta kurangnya kreativitas guru dalam menggunakan bahan ajar berbasis multimedia.

Merujuk pada permasalahan di atas, ada beberapa cara yang dapat dilakukan guru. Salah satu alternatif yang dapat digunakan adalah dengan mendesain bahan ajar berbasis multimedia dengan menggunakan aplikasi adobe flash. Bahan ajar memiliki posisi yang sangat penting dalam pembelajaran. Bahan ajar menurut Pannen (dalam Andi Prastowo, 2013:17) adalah "bahan-bahan atau materi pelajaran yang disusun secara sistematis yang digunakan guru dan siswa dalam proses pembelajaran”. Suatu proses pembelajaran akan lebih bermakna jika siswa memiliki motivasi yang tinggi dalam proses pembelajaran.

Salah satu bahan ajar yang masih jarang dikembangkan guru dalam pembelajaran adalah game edukasi berbasis multimedia.Game edukasi merupakan bentuk permainan yang dirancang untuk membantu pembelajaran mencapai tujuan pembelajaran tertentu sekaligus memberikan motivasi. Usia anak-anak cenderung lebih menggemari game daripada membaca buku-buku mata pelajaran. Hal ini dikarenakan game memiliki desain yang menarik dan berisikan animasi yang menarik. Pengembangan bahan ajar yang dikembangkan adalah bahan ajar berbasis multimedia dengan memanfaatkan software adobe flashCS3. Pembuatan bahan ajar 
dengan menggunakan Adobe Flash CS3 diharapkan mampu menarik minat peserta didik dalam belajar matematika. Selain itu, dengan bahan ajar ini diharapkan peserta didik lebih bersemangat dalam belajar menggunakan bahan ajar berbasisi multimedia.

Mulitimedia dapat mengembangkan kemampuan indera dan menarik perhatian serta minat. Computer Technology Research (CRT), menyatakan bahwa orang hanya mampu mengingat $20 \%$ dari yang dilihat dan $30 \%$ dari yang didengar. Tetapai orang yang dapat mengingat 50\% dari yang dilihat dan didengar dan $80 \%$ dari yang dilihat, didengar dan dilakukan sekaligus. Multimedia dapat menyajikan informasi yang dapat dilihat, didengar dan dilakukan, sehingga multimedia sangatlah efektif untuk menjadi alat (tools) yang lengkap dalam proses pengajaran dan pembelajaran ( Murni, 2015: 6 ).

Pengembangan Menurut (Suryani dkk,2018: 54), menyatakan media pembelajaran berbasis computer merupakan cara memproduksi dan menyampaikan materi dengan menggunakan sumber-sumber yang berbasis digital. Solusinya, yaitu dengan menggunakan Game Edukasi adobe flash CS3 meningkatkan keaktifan siswa dikelas dan memberikan suasana pembelajaran yang lebih menarik serta lebih menumbuhakan semangat belajar siswa pada mata pelajaran matematika.

\section{METODE PENELITIAN}

Pengembangan bahan ajar game Edukasi adobe flash untuk berhitung cepat ini menggunakan metode penelitian (research and development) Metode research and development adalah metode penelitian yang digunakan untuk mengasilkan produk tertentu, dan menguji keefektifan prodak tersebut. Untuk dapat mengasilkan produk tertentu digunakan penelitian yang persifat analisis kebutuhan dan untuk menguji keefektifan produk tersebut supaya dapat berfungsi di masyarakat luas, maka diperlukan penelitian untuk menguji keefektifan produk tersebut. Jadi penelitian dan pengembangan bersifat longitudinal (bertahap bisamulti years). (Sugiono, 2018: 297).

Prosedur pengembangan ini mendapatkan model pengembangan ADDIE, yaitu model pengembangan yang terdiri dari lima tahapan yang terdiri dari analisis, desain, pengembangan, implementasi, dan evaluasi. Penelitian ini dilaksanakan di MI 
NW Hidayatul Ikhwan yang bertempat Desa Bungtiang Kecamatan Sakra Barat. Pelaksanaan penelitian ini dilakukan pada tanggal 21 Agustus 2019

Subjek uji coba yang akan terlibat adalah satu orang ahli media, satu orang ahli materi, praktisi pembelajaran matematika (guru matematika MI NW Hidayatul Ikhwan Bungtiang) dan 19 siswa kelas 2 MI NW Bungtiang. Uji coba yang akan diteliti adalah kualitas dan kelayakan bahan ajar berbasis game Edukasi adobe flash yang merupakan aspek evaluasi/latihan soal, aspek tampilan visual, aspek perangkat lunak dan aspek efek bagi stratergi pembelajaran.

Teknik Pengumpulan Data, 1). Kuesioner/angket Menurut Sugiyono (2018: 142), kuesioner/angket adalah teknik pengumpulan data yang dilakukan dengan cara memberi seperangkat pertanyaan atau pernyataan tertulis kepada responden. 2). Observasi Menurut Sugiono (208:145), menyatakan bahwa observasi adalah suatu proses yang kompleks, suatu proses yang tersusun dari berbagai proses biologis maupun psikologis. Dua diantaranya yang terpenting adalah proses-proses pengamatan dan ingatan.

Instrumen Pengumpulan Data Instrumen yang digunakan dalam penelitian ini merupakan kuesioner/ angket. Angket tersebut berisi butir-butir pernyataan untuk diberi tanggapan oleh responden. Menurut Prasetyo (2015: 29), angket adalah daftar pernyataan atau pertanyaan yang dikirimkan kepada responden baik secara langsung atau tidak langsung.

Analisis data merupakan setelah data dari seluruh responden terkumpul. Dalam penelitian ini, teknik analisis data menggunakan teknik analisis deskriptif yang kemudian dimaknai. Menurut Sugiono (2018: 147), skala Likert Untuk menghindari kecenderungan responden asal isi dan memilih skor tengah dari skala yang digunakan, maka peneliti menggunakan skala lima. Jawaban setiap item instrument menggunakan Skala Likert mempunyai gradasi dari sangat positif sampai sangat negatif. Skalanya sebagai berikut (Sugiono, 2018: 93):

\section{HASIL PENELITIAN DAN PEMBAHASAN}

Kelayakan bahan ajar diketahui melalui tahap validasi oleh ahli. Validator yang dipilih oleh peneliti terdiri dari satu dosen ahli tampilan, satu guru kelas ahli materi, 19 siswa pada uji coba lapangan. Instrumen pengumpulan data menggunakan angket kelayakan bahan ajar game edukasi dengan skala 1-5. 
Berdasarkan lima tahapan penilaian kelayakan bahan ajar game edukasi dapat disimpulakan bahwa bahan ajar game edukasi memperoleh nilai interval 33 dengan rata-rata skor 3,6 di ahli tampilan termasuk dalam kategori "setuju" dengan rentang nilai 30,6 $\geq X \leq 37,8,15$ di ahli materi memperoleh nilai interval 20 dengan rata-rata skor 4 dalam kategori "setuju” dengan rentang nilai $16,98 \geq X \leq 20,94$.

Perolehan data uji coba menggunakan angket respon siswa dan lembar observasi. Tujuan dari uji coba ini adalah untuk memperoleh data tentang keterlaksanaan pembelajaran yang dihasilkan dan merupakan bagian dari upaya untuk memperoleh kualitas produk yang dihasilkan. Berdasarkan data hasil respon siswa terhadap produk setelah siswa belajar menggunakan bahan ajar berbasis aplikasi game edukasi adobe flash dalam proses pembelajaran menunjukan jumlah untuk respon ragu 51, respon setuju 63 dan respon sangat setuju 63 dalam 15 pernyataan yang di respon oleh 19 orang siswa.

Berdasarkan data hasil lembar observasi aktivitas siswa selama pembelajaran berlangsung menggunakan bahan ajar berbasis aplikasi game edukasi adobe flash yang diperoleh pada uji coba yang telah dilakukan pada 10 item pernyataan penilaian diketahui jumlah skor aktual 39 dengan rata-rata 3,9. Sehingga aktivitas yang dihasilkan oleh siswa ketika proses pembelajaran berlangsung menggunakan bahan berbasis aplikasi game edukasi adobe flash pada uji berkriteria "baik".

Pengembanagan bahan ajar siswa pada materi penjumlahan dan pengurangan yang dilakukan pada penelitian ini merupakan salah satu usaha untuk mengembangkan bahan ajar pada mata pelajaran matematika khususnya pada materi penjumlahan dan pengurangan. Pengembangan bahan ajar siswa dengan media pembelejaran game edukasi adobe flash ini dilakukan dengan harapan dapat meningkatkan kemampuan berfikir kreatif siswa dalam pemecahan masalah matematika. Maka bahan ajar siswa dengan bahan ajar game edukasi adobe flash pada materi penjumlahan dan pengurangan ini dikatakan valid. Tergambar dari hasil penilaian validator, dimana semua validator menyatakan baik berdasarkan isi materi, musik, gambar, jenis tulisan, animasi, kemudahan tombol dan soal-soal materi, serta desain pembelajaran dengan bahan ajar game edukasi adobe flash.

Hal ini juga didukung oleh penyempurnaan bahan ajar siswa dari hasil uji coba perorangan. Selain itu, bahan ajar ini dapat mengurangi suasana kurang kondusif 
didalam kelas dan juga dapat melibatkan semua siswa aktif mengikuti kegiatan pembelajaran pemecahan masalah matematika dengan memberikan penjelasan tahap game edukasi adobe flash yang akan dilakukan selama pembelajaran. Maka dari itu, bahan ajar dengan game edukasi adobe flash ini sangat bagus digunakan dan merupakan suatu solusi untuk membantu siswa dan guru dalam pembelajaran matematika yang bertujuan meningkatkan kemampuan berfikir kreatif siswa dalam pemecahan masalah matematika.

\section{KESIMPULAN}

Berdasarkan hasil penilain daripengembangan bahan ajar berbasis aplikasi game adobe flash CS3 untuk edukasi peserta didik dalam berhitung cepat mata pelajaran matematika.

1. Telah dikembangakan bahan ajar game edukasi sesuai dengan prosedur pengembangan yang dilakuakan dengan mengadopsi model pengembangan ADDIE dengan prosedur sebagai berikut: (1) analisis (2) desain (3) pengembangan (4) implementasi (5) evaluasi.

2. Berdasarkan angket respon siswa dan observasi aktivitas siswa di MI NW Bungtiang setelah dilakukan uji coba lapangan dengan jumlah siswa 19, dengan persentase $10 \%$. Hal ini menunjukkan bahwa dengan menggunakan bahan ajar berbasis game edukasi yang telah dikembangakan dapat mempengaruhi hasil belajar siswa serta sudah dianggap layak untuk digunakan dalam proses pembelajaran.

3. Data hasil dari revisi akhir bahwa bahan ajar hanya perlu dipenambahan tombol kembali pada layer game over supaya produk yang dikembangakan layak untuk digunakan selamanya.

\section{DAFTAR PUSTAKA}

Atiaturrahmaniah, DSM Ibrahim, (2017). Pengembangan Media Pembelajaran Berbasis Adobe Flash Dengan Penerapan Teori Van Hiele. Jurnal Didika. Vol. 1. No.1. Hal 2

Andi prastowo, (2015). Panduan Kreatif Membuat Bahan Ajar Inovatif. Jogjakarta: DIVA Press 
Rusdi, (2018). Penelitian Desaian Dan Pengembangan Kependidikan. Depok: PT Rajagrafindo Persada

Sugiyono, (2018). Metode Penelitian Kuantitatif, Kualitatif, Dan R\&D. Bandung: Alfabeta CV

Suryani dkk, (2018). Media Pembelajaran Inovatif dan Pengembangannya. Bandung: PT Remaja Rosdakarya

Susanto, (2014). Teori Belajar Dan Pembelajaran Di Sekolah Dasar. Kencana: PT Fajar Interpratama Mandiri 